\title{
DNA methylation and mRNA expression profiles in bovine oocytes derived from prepubertal and adult donors
}

\author{
Mike Diederich, Tamara Hansmann, Julia Heinzmann, Brigitte Barg-Kues, Doris Herrmann, \\ Patrick Aldag, Ulrich Baulain, Richard Reinhard ${ }^{2}$, Wilfried Kues, Christian Weißgerber ${ }^{1}$, \\ Thomas Haaf ${ }^{1}$ and Heiner Niemann
}

Institute of Farm Animal Genetics (FLI), 31535 Mariensee, Neustadt, Germany, ${ }^{1}$ Institute of Human Genetics, Julius Maximilians University, 97074 Wuerzburg, Germany and ${ }^{2}$ Max Planck Institute for Plant Breeding Research, 50829 Cologne, Germany

Correspondence should be addressed to H Niemann; Email: heiner.niemann@fli.bund.de

\begin{abstract}
The developmental capacity of oocytes from prepubertal cattle is reduced compared with their adult counterparts, and epigenetic mechanisms are thought to be involved herein. Here, we analyzed DNA methylation in three developmentally important, nonimprinted genes (SLC2A1, PRDX1, ZAR1) and two satellite sequences, i.e. 'bovine testis satellite I' (BTS) and 'Bos taurus alpha satellite I' (BT $\alpha$ S). In parallel, mRNA expression of the genes was determined by quantitative real-time PCR. Oocytes were retrieved from prepubertal calves and adult cows twice per week over a 3-week period by ultrasound-guided follicular aspiration after treatment with FSH and/or IGF1. Both immature and in vitro matured prepubertal and adult oocytes showed a distinct hypomethylation profile of the three genes without differences between the two types of donors. The methylation status of the BTS sequence changed according to the age and treatment while the methylation status of $\mathrm{BT} \alpha \mathrm{S}$ sequence remained largely unchanged across the different age and treatment groups. Relative transcript abundance of the selected genes was significantly different in immature and in vitro matured oocytes; only minor changes related to origin and treatment were observed. In conclusion, methylation levels of the investigated satellite sequences were high $(>50 \%)$ in all groups and showed significant variation depending on the age, treatment, or in vitro maturation. To what extent this is involved in the acquisition of developmental competence of bovine oocytes needs further study.

Reproduction (2012) 144 319-330
\end{abstract}

\section{Introduction}

The use of bovine oocytes from prepubertal animals for embryo production in vitro could accelerate genetic gain and shorten generation intervals (Lohuis 1995). However, currently the average rates of viable blastocysts produced from prepubertal donor oocytes are lower than the use of adult oocytes (10-15 vs $~ 30 \%$; Oropeza et al. 2004, Zaraza et al. 2010). Incomplete or deficient cytoplasmic maturation, altered protein synthesis, reduced oocyte size, and impaired metabolism in prepubertal oocytes have been proposed as possible mechanisms for the reduced developmental potential (Lonergan et al. 1994, Steeves et al. 1999, De Paz et al. 2001, Kauffold et al. 2005).

The intraovarian (i.o.) injection of insulin-like growth factor 1 (IGF1) has been shown to improve the developmental competence of prepubertal oocytes (Oropeza et al. 2004). Embryos produced from oocytes derived from IGF1-treated prepubertal donors showed similar developmental potential and a similar mRNA expression profile of genes critical in embryonic development as those produced from adult donors (Oropeza et al. 2004). Epigenetic factors were proposed to be involved in the acquisition of full developmental competence of bovine prepubertal oocytes, but have not yet been studied in detail (Oropeza et al. 2004, Zaraza et al. 2010).

DNA methylation at the CpG dinucleotides is one of the major epigenetic modifications in eukaryotic genomes. In somatic cells $\sim 60-90 \%$ of the CpG dinucleotides are methylated, mainly in noncoding regions of the genome (Siegfried \& Cedar 1997). During gametogenesis and early embryogenesis, the genome undergoes waves of demethylation and remethylation (Jaenisch 1997, Kageyama et al. 2007). In the first round of epigenetic reprogramming a sex-specific methylation pattern of certain loci, i.e. genomic imprinting, is established in the male and female germ lines. After fertilization, the second round of epigenetic reprogramming of the female and male genomes is essential for the activation or silencing of specific genes and creates the methylation pattern compatible with normal 
development (Jaenisch 1997, Kageyama et al. 2007, Sato et al. 2007, Lees-Murdock \& Walsh 2008).

Here, we investigated the potential impact of age (prepubertal vs adult) and hormonal treatment (FSH and IGF1) of the donor animal on: i) DNA methylation and ii) mRNA expression of developmentally important, nonimprinted genes in bovine oocytes. We applied the recently developed and validated limiting dilution approach and direct bisulfite sequencing (El Hajj et al. 2011, Heinzmann et al. 2011) to analyze the methylation profile of individual DNA molecules in three nonimprinted genes, including solute carrier family 2 member 1 (SLC2A1/facilitated glucose transporter), peroxiredoxin 1 (PRDX1), and zygotic arrest gene 1 (ZAR1) from prepubertal and adult oocytes, collected from donors with and without treatment with $\mathrm{FSH}$.

In addition, we analyzed differences in DNA methylation of two satellite sequences, i.e. 'bovine testis satellite I' (BTS) and 'Bos taurus alpha satellite I' (BT $\alpha \mathrm{S}$ ) by classical bisulfite sequencing. Furthermore, we analyzed the mRNA expression levels of the above genes, indicative of the developmental potential of oocytes, including growth factor response (growth differentiation factor 9 (GDF9)), response to oxidative stress (PRDX1), a maternal factor (ZAR1), and transport of energy (SLC2A1).

\section{Results}

Calves were randomly assigned to four groups (calf, without treatment; calf FSH, i.m. FSH treatment; calf FSH+IGF1, i.m. FSH treatment+i.o. IGF1 injection; and calf FSH+IGF C, FSH+i.o. 0.01 M acetic acid injection). Cows were divided into two groups (cow, no treatment and cow FSH). Oocytes were retrieved by ovum pick-up (OPU) and used either directly for analysis or subjected to in vitro maturation (IVM). The numbers of aspirated follicles, retrieved oocytes, and oocytes used for experiments did not differ significantly between treatment groups (Table 1). Maturation rates did not differ significantly between groups (Table 1 ).

\section{Methylation analysis}

\section{Methylation profile of two satellite DNA sequences}

We examined the methylation status of two representative satellite DNA sequences, the BTS and BT $\alpha$ S that are indicative of global methylation dynamics, in the genome in prepubertal and adult bovine oocytes. For analysis of the BTS sequence, a 211 bp segment of the satellite sequence, including 12 highly conserved CpGs sites, was amplified by PCR from bisulfite-treated genomic DNA, and the resulting PCR products were individually cloned and sequenced (Kang et al. 2001, 2005). A 154 bp region was amplified by PCR which included nine $\mathrm{CpG}$ s for analysis of the $\mathrm{BT} \alpha \mathrm{S}$ sequence in immature and in vitro matured bovine oocytes.

The genome of immature oocytes displayed differential methylation for the BTS sequence between the experimental groups. In the group ' $\mathrm{Cow}^{\prime}$ ' the methylation of BTS I was $49.6 \%$ for immature oocytes, whereas methylation rates for the groups 'calf' $(74.6 \%)$ and 'cow $\mathrm{FSH}^{\prime}(69.8 \%)$ were significantly higher (Table 2). After IVM a significant difference was observed between the groups 'calf' (53.3\%) and 'calf FSH+IGF1' (71.7\%) (Table 2). Within the age and treatment groups, we observed significant differences $(P<0.05)$ prior to and after IVM in groups 'Cow' (49.6 vs $64.9 \%$ ) and 'calf FSH+IGF1' (60.6 vs $71.7 \%$ ) and 'calf' (74.6 vs $53.4 \%$ ) (Table 2). A representative methylation profile for the BTS sequence is shown in Supplementary Figure 1, see section on supplementary data given at the end of this article.

The methylation level of the BTaS sequence was higher in immature oocytes than in in vitro matured oocytes, but did not differ significantly between groups and treatments (Table 3). Within groups, before and after IVM a significant decrease in methylation $(P<0.05)$ was shown for 'Cow FSH' (76.2 vs 52.5\%) and 'calf $\mathrm{FSH}^{\prime}$ (72.8 vs $57.8 \%$ ). A representative methylation profile for the BT $\alpha$ S sequence is shown in Supplementary Figure 2, see section on supplementary data given at the end of this article.

\section{Gene-specific methylation}

Most gene-specific methylation analyses in oocytes have been performed with large pools of (100 or more) cells (Lucifero et al. 2002, Anckaert et al. 2010). However, when working with such small amounts of DNA, degradation and low complexity of bisulfite-converted DNA may lead to stochastic amplification of a single or only few molecules in the starting sample and may thus yield nonrepresentative results. To avoid amplication

Table 1 Ovum pick-up and morphological quality of oocytes from calves and cows.

\begin{tabular}{lccccc}
\hline $\begin{array}{l}\text { Groups (no. of } \\
\text { animals) }\end{array}$ & $\begin{array}{c}\text { No. of aspirated } \\
\text { follicles }\end{array}$ & $\begin{array}{c}\text { Total no. of retrieved } \\
\text { oocytes }\end{array}$ & $\begin{array}{c}\text { No. of oocytes (class I } \\
\text { and II) }\end{array}$ & $\begin{array}{c}\text { No. of oocytes used } \\
\text { for IVM (class I and II) }\end{array}$ & $\begin{array}{c}\text { Matured oocytes (\%) } \\
\text { Calf (31) }\end{array}$ \\
Calf FSH (35) & 954 & 725 & 225 & 124 & 50 \\
Calf FSH + IGF1 (30) & 1096 & 797 & 262 & 175 & 40 \\
Calf FSH+ IGF C (27) & 1212 & 995 & 287 & 180 & 50 \\
Cow (26) & 1201 & 923 & 263 & 162 & 50 \\
Cow FSH (17) & 1287 & 827 & 273 & 102 & 50 \\
\hline
\end{tabular}


Table 2 Methylation pattern of 'bovine testis satellite I (BTS) sequence' (X士s.E.M.).

\begin{tabular}{llc}
\hline Group & $\begin{array}{c}\text { Immature } \\
\text { oocytes; } \\
\text { methylation }(\%)\end{array}$ & $\begin{array}{c}\text { In vitro matured } \\
\text { oocytes; } \\
\text { methylation }(\%)\end{array}$ \\
\hline Cow & $49.6 \pm 3.5^{\mathrm{c}, \mathrm{A}}$ & $64.9 \pm 6.3^{\mathrm{a}, \mathrm{b}, \mathrm{B}}$ \\
Cow FSH & $69.8 \pm 3.4^{\mathrm{a}, \mathrm{b}}$ & $59.7 \pm 3.7^{\mathrm{a}, \mathrm{b}}$ \\
Calf & $74.6 \pm 3.9^{\mathrm{a}, \mathrm{A}}$ & $53.4 \pm 5.4^{\mathrm{b}, \mathrm{B}}$ \\
Calf FSH & $64.7 \pm 3^{\mathrm{a}, \mathrm{b}, \mathrm{c}}$ & $63.3 \pm 5.7^{\mathrm{a}, \mathrm{b}}$ \\
Calf FSH + IGF1 & $60.6 \pm 3.4^{\mathrm{a}, \mathrm{b}, \mathrm{c}, \mathrm{A}}$ & $71.7 \pm 5.2^{\mathrm{a}, \mathrm{B}}$ \\
Calf FSH + IGF C & $69.6 \pm 5.9^{\mathrm{a}, \mathrm{b}, \mathrm{c}}$ & $62.5 \pm 4.5^{\mathrm{a}, \mathrm{b}}$ \\
\hline
\end{tabular}

Methylation pattern of 'BTS sequence' in immature and in vitro matured oocytes of different experimental groups. Significant differences within groups of immature and in vitro matured oocytes groups are characterized by small letters $(a, b, c)$. Differences between immature and in vitro matured oocytes are characterized by capital letters (A, B). Different superscripts indicate significant differences $(P \leq 0.05)$.

bias and to recover as many DNA molecules as possible from small oocyte pools, we have used limiting dilution of bisulfite-treated DNA from ten cells each, combined with multiplex PCR and direct bisulfite sequencing of three representative nonimprinted genes. A schematic drawing of the basic steps of the protocol is shown in Fig. 1. The sequestration of individual DNA molecules from the starting sample in separate PCR reactions ensures that each generated bisulfite amplicon represents an individual DNA molecule in the starting sample.

Here, we analyzed promoter methylation of $S L C 2 A 1$, $P R D X 1$, and ZAR1 in bovine oocytes retrieved from prepubertal and adult donors. The GDF9 promoter sequence did not contain CpGs and was excluded from this analysis. Immature oocytes are arrested in meiotic prophase I and contain four paired chromatids (DNA molecules). After maturation, the oocyte is arrested in metaphase II with two chromatids in the oocyte and two in the attached first polar body. Thus, pools of ten immature or mature oocytes are endowed with 40 copies of each studied gene, implying that a maximum of 120 target DNA molecules are present for multiplex PCR with three genes. The amplicons for direct bisulfite sequencing included $14 \mathrm{CpG}$ sites for $S L C 2 A 1$, 17 CpGs for PRDX1, and 18 CpGs for ZAR1.

On average, we recovered 12.9 of the 120 target molecules per pool of immature and 12.3 per pool of in vitro matured oocytes (Table 4). For immature oocytes, we obtained 26.3 copies per gene in the group 'Cow', 16.7 in 'cow FSH', 5.3 in 'calf', 18.3 in 'calf FSH', 11.3 in 'calf FSH+IGF1', and 8.0 in 'calf FSH+IGF C'. For in vitro matured oocytes, we obtained on average 26.3 copies in the group ' $\mathrm{COW}^{\prime}, 20.7$ in 'Cow FSH', 17.7 in 'calf', 7.7 in 'calf FSH', 13.7 in 'calf FSH+IGF1', and 12.7 in 'calf FSH + IGF C'. All recovered DNA molecules were demethylated, as expected for the SLC2A1, $P R D X 1$, and ZAR1 promoter regions in oocytes. None of 258 DNA molecules from immature and of 296 from in vitro matured oocytes showed $>50 \%$ methylation, indicating that epimutations (at least in the three studied genes) are extremely rare or lack completely in the analyzed groups. Consistent with our recent studies (El Hajj et al. 2011, Heinzmann et al. 2011), the rate of single methylated $\mathrm{CpG}$ sites in the three studied genes varied between 0 and $2.4 \%$ (data not shown). No significant differences $(P>0.05)$ existed between the different oocyte groups.

\section{Determination of the relative $m R N A$ abundance of developmentally important genes in bovine oocytes}

The relative mRNA abundance of the four developmentally important, nonimprinted genes (GDF9, $S L C 2 A 1, P R D X 1$, and ZAR1) selected for this study was investigated in immature and in vitro matured oocytes of the different age and treatment groups. No significant differences were observed for all four genes in immature oocytes. However, after maturation we observed significant reductions in transcript abundance for GDF9 and ZAR1 in all groups (Fig. 2). The ZAR1 transcript was reduced after IVM in hormonally treated animals compared with untreated animals.

Transcript levels of $P R D X 1$ were significantly reduced $(P<0.05)$ after maturation in all groups with the exception of ' calf FSH+IGF C' (Fig. 2). A slight but nonsignificant increase of $P R D X 1$ transcripts was observed in in vitro matured oocytes after hormonal treatment. SLC2A1 was significantly downregulated in the groups 'cow', 'cow FSH', 'calf', and 'calf FSH' after IVM. The observed difference in the transcript level for the groups 'calf FSH+IGF1' and 'calf FSH+IGF C' did not reach the level of statistical significance (Fig. 2).

\section{Discussion}

Epigenetic mechanisms, specifically DNA methylation dynamics, have been implicated in the low developmental capacity of juvenile oocytes (Oropeza et al. 2004, Zaraza et al. 2010). In the study presented here, we investigated for the first time the influence of donor age and hormonal treatments on the general DNA

Table 3 Methylation pattern of 'Bos taurus alpha satellite I (BT $\alpha \mathrm{S})$ ' $(\mathrm{X} \pm$ S.E.M. $)$

\begin{tabular}{lcc}
\hline Group & $\begin{array}{c}\text { Immature } \\
\text { oocytes; } \\
\text { methylation }(\%)\end{array}$ & $\begin{array}{c}\text { In vitro matured } \\
\text { oocytes; } \\
\text { methylation }(\%)\end{array}$ \\
\hline Cow & $66.4 \pm 4.2$ & $61.7 \pm 2.1$ \\
Cow FSH & $76.7 \pm 4^{\mathrm{A}}$ & $52.5 \pm 4.1^{\mathrm{B}}$ \\
Calf & $73 \pm 2.7$ & $70 \pm 4.1$ \\
Calf FSH & $72.8 \pm 3.6^{\mathrm{A}}$ & $57.8 \pm 2.7^{\mathrm{B}}$ \\
Calf FSH + IGF1 & $66 \pm 3.1$ & $56.8 \pm 2.2$ \\
Calf FSH + IGF C & $68.9 \pm 3.1$ & $62.9 \pm 3.9$ \\
\hline
\end{tabular}

Methylation pattern of ' $\mathrm{BT} \alpha \mathrm{S}$ ' in immature andin vitro matured oocytes of different groups. Significant differences after IVM are characterized by capital letters $(A, B)$. Different superscripts indicate significant difference $(P \leq 0.05)$. 


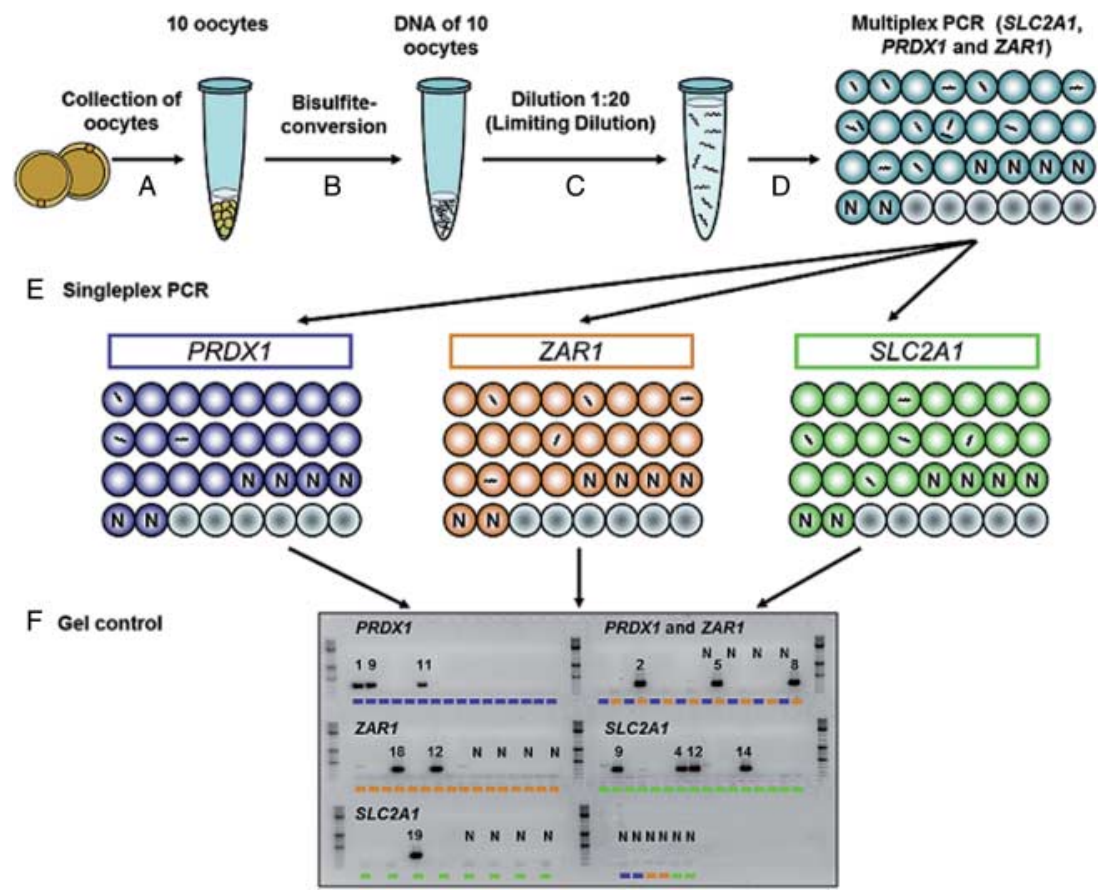

Figure 1 Schematic drawing of the main steps of limiting dilution bisulfite sequencing. (A) Immature and mature oocytes are collected by OPU or after IVM. Ten oocytes of a defined group are pooled. (B) DNA isolation and bisulfite conversion. (C) Dilution of the converted oocyte DNA. (D) The diluted DNA is distributed over 20 wells on a microtiter plate. Most wells contain either no or a single DNA target molecule (ideograms); few wells may contain two or more copies. In addition, six negative controls $(\mathrm{N})$ are added. First-round multiplex PCR is performed with outer primers for the PRDX1, ZAR1, and SLC2A1 genes. (E) Second-round singleplex PCRs of the three studied genes in individual microtiter plates (indicated by different colors) using $1 \mu$ multiplex PCR product as template and gene-specific inner primers. (F) Second-round PCR products are visualized on agarose gels. The color code of each lane indicates the plate (gene), numbers, and Ns of the specific well on that plate. DNA from wells containing a PCR product is analyzed by direct bisulfite sequencing.

methylation dynamics and concomitantly the methylation status of selected genes, including $S L C 2 A 1$, $P R D X 1$, and ZAR1 in bovine oocytes. Moreover, the mRNA expression levels of these genes were determined in immature and in vitro matured oocytes to correlate transcript abundance with DNA methylation.

Several studies have reported that DNA methylation plays a crucial role in gametogenesis and early embryonic development (Cheung et al. 2009, Katari et al. 2009). Approximately $60 \%$ of the genes in the mammalian genome show a high CpG density in their promoters, called CpG islands (Antequera \& Bird 1993). Usually, a low level of DNA methylation in the promoter region is associated with active transcription (Neumann \& Barlow 1996), while high levels of methylation are correlated with low or no expression (Suzuki \&
Bird 2008). In contrast to the rest of the genome where most CpGs are methylated, CpG islands in $5^{\prime}$ cis-regulatory (promoter and first exon) regions of genes are normally unmethylated. Methylation of these CpG islands during the development or diseases is associated with gene silencing (Jaenisch \& Bird 2003, Weber et al. 2007). Here, we found distinctive hypomethylation in all experimental groups regardless of maturation, age, or prior hormonal treatment for the developmentally important genes $S L C 2 A 1, P R D X 1$, and $Z A R 1$, suggesting that the expression of these genes is not regulated by promoter methylation. Therefore, other mechanisms, i.e. gene body methylation (Maunakea et al. 2010), may be more important for regulating oocyte-specific efficiency of transcription. However, one has to take into account that the data presented here

Table 4 Number of analyzed DNA molecules in three nonimprinted genes in bovine oocytes.

\begin{tabular}{|c|c|c|c|c|c|c|c|}
\hline \multirow[b]{2}{*}{ Oocyte group } & \multirow[b]{2}{*}{$\begin{array}{c}\text { Number of } \\
\text { pools }\end{array}$} & \multicolumn{3}{|c|}{ Number of analyzed DNA molecules } & \multicolumn{3}{|c|}{ All three genes } \\
\hline & & SLC2A1 & PRDX1 & ZAR1 & $\begin{array}{c}\text { Number of DNA } \\
\text { molecules }\end{array}$ & $\begin{array}{l}\text { DNA molecules } \\
\text { per gene }\end{array}$ & $\begin{array}{l}\text { DNA molecules } \\
\text { per pool }\end{array}$ \\
\hline Immature oocytes & & & & & 258 & 12.9 & 14.3 \\
\hline Cow & 4 & 33 & 18 & 28 & 79 & 19.8 & 26.3 \\
\hline Cow FSH & 4 & 20 & 10 & 20 & 50 & 12.5 & 16.7 \\
\hline Calf & 1 & 6 & 7 & 3 & 16 & 16 & 5.3 \\
\hline Calf FSH & 5 & 26 & 16 & 13 & 55 & 11 & 18.3 \\
\hline Calf FSH+IGF1 & 3 & 18 & 5 & 11 & 34 & 11.3 & 11.3 \\
\hline Calf FSH+IGF C & 3 & 12 & 1 & 11 & 24 & 8 & 8 \\
\hline Mature oocytes & & & & & 296 & 12.6 & 15.4 \\
\hline Cow & 5 & 33 & 18 & 28 & 79 & 15.8 & 26.3 \\
\hline Cow FSH & 4 & 28 & 10 & 24 & 62 & 15.5 & 20.7 \\
\hline Calf & 4 & 18 & 10 & 25 & 53 & 13.3 & 17.7 \\
\hline Calf FSH & 4 & 7 & 5 & 11 & 23 & 5.8 & 7.7 \\
\hline Calf FSH+IGF1 & 4 & 17 & 6 & 18 & 41 & 10.3 & 13.7 \\
\hline Calf FSH+IGF C & 3 & 13 & 10 & 15 & 38 & 12.7 & 12.7 \\
\hline
\end{tabular}




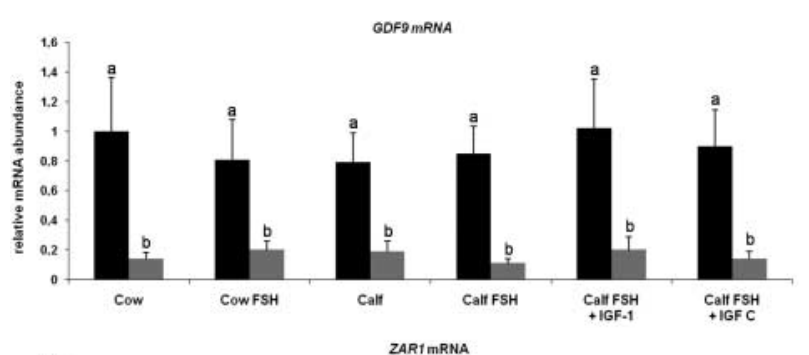

decreased significantly during IVM, the methylation rates increased after IVM for oocytes from untreated cows and calves treated with both FSH and IGF1. This suggests that the treatment of calves with FSH and IGF1 prior to OPU renders the epigenetic status of the oocyte closer to that of the adult untreated oocyte. Recently, O'Doherty et al. (2012) reported size-dependent methylation dynamics in growing bovine oocytes, possibly linking the acquisition of developmental competence with the acquisition of specific methylation.

Oocytes from all prepubertal and adult experimental groups uniformly showed reduced methylation levels for the satellite sequence BT $\alpha$ S after IVM. The methylation levels found in this study were higher than that reported previously for bovine matured oocytes $(\sim 5.5 \%$; Kang et al. 2005). Whether or not the fertilization process affects the methylation status in a significant manner remains to be determined. In sheep oocytes, the level of DNA methylation was significantly decreased in prepubertal oocytes compared with their adult counterparts (Ptak et al. 2006).

It is crucial to discriminate between methylation of single CpG sites and methylation of the entire cisregulatory region. A single or a few methylated CpGs within an overall nonmethylated promoter most likely represent a technical error during bisulfite conversion or a stochastic biological phenomenon without functional consequences. Although in some genomic regions methylation of a single CpG (i.e. in a transcription factor binding site) may interfere with gene regulation (Griswold \& Kim 2001), it is usually the density of methylated $\mathrm{CpG}$ rather than individual $\mathrm{CpGs}$ that switch a promoter on or off. Because individual CpGs cannot maintain methylation that is different from those of the neighboring CpGs, usually the entire promoter is either methylated or nonmethylated (Sontag et al. 2006, Weber et al. 2007). Consequently, only DNA molecules with $>50 \%$ methylated CpGs can be considered as epimutations that are associated with gene silencing.

Most repetitive DNA elements are densely methylated

provide only a narrow window into methylation dynamics in immature and in vitro matured oocytes and age and/or hormonal treatment dependent methylation changes can have profound effects on functionality (Laird 2005, Wilkins-Haug 2009).

In order to achieve a more general overview of the methylation patterns of oocytes in all experimental groups, we investigated two repeat sequences: the BTS and the BTaS sequence. Previously, a moderate methylation level (27.9-35\%) was reported for bovine 1-cell embryos (Kang et al. 2001, 2005). Here, we showed hypermethylation (52-71\%) in most groups of juvenile and adult oocytes, suggesting maternal epigenetic regulation of this specific repeat sequence during oogenesis and oocyte maturation. Methylation dynamics differed between groups for the BTS sequence. While the methylation level for untreated calves in somatic cells. Hypomethylation of centromeric satellite DNAs can lead to a decondensed chromatin structure and chromosomal (centromeric) instability (Miniou et al. 1994, Haaf 1995). On the other hand, demethylation of interspersed repetitive elements is frequently associated with the reactivation of retrotransposons and thus promotes genome instability by insertional mechanisms (Yoder et al. 1997). It was therefore not surprising that satellite sequences (and some other genomic sequences) are rather resistant against changes in DNA methylation and may have their own regulatory mechanisms. The high preservation of methylation marks at the BTS sequences during early embryo development suggests efficient maintenance of methylation in bovine embryos (Kang et al. 2005). Recently, it was shown that the methylation status of the oocyte correlates with follicle size, size of the oocyte, 
and oocyte developmental capacity (Fagundes et al. 2011). While immature oocytes from follicles $\geq 8 \mathrm{~mm}$ showed significantly higher methylation than their matured counterparts from follicles of the same size category, oocytes from follicles $1-3 \mathrm{~mm}$ in diameter did not exhibit differences prior to and after maturation (Fagundes et al. 2011). In the present study, we used oocytes from follicles $>3 \mathrm{~mm}$ in size. Deviations from the physiological methylation profile were found in mouse embryos with deficient development and were attributed to the culture system and the different genetic background of the mouse strains (Shi \& Haaf 2002). Hypomethylation of minor and major satellite sequences was shown for prepubertal mouse oocytes (Sanford et al. 1984, Monk et al. 1987). The centromeric satellite sequence (Rsat IIE) was moderately methylated with $47.6 \pm 23.2 \%$ in adult rabbit oocytes, which is comparable with the results found for the BTaS sequence in this study. These data indicate that species-specific differences exist with regard to satellite methylation during mammalian oocyte development.

Gene expression in the mammalian oocyte is subject to specific temporal and spatial control mechanisms. During oogenesis, oocytes synthesize substantial amounts of mRNA that are accumulated in the cytoplasm (Fair et al. 1995, Hyttel et al. 1997, Picton et al. 1998, Memili \& First 2000). During maturation, fertilization, and early embryonic development the stored maternal mRNAs are essential for development, and transcription is resumed with the activation of the embryonic genome (Niemann \& Wrenzycki 2000, Thélie et al. 2007).GDF9 is important for growth and proliferation of cells. The highest concentration of GDF9 transcripts was found in immature oocytes, while GDF9 abundance was reduced after maturation. Similar findings were reported previously and specifically the reduction in GDF9 mRNA transcript abundance was linked to the acquisition of developmental competence (Lonergan et al. 1994, 2003). While the mRNA content prior to and after IVM differed significantly for all treatment groups in this study, there were no significant differences between the groups of donors. Similar findings were made for $Z A R 1$, an important maternal effect gene regulating early embryonic development (Duranthon \& Renard 2001, Brevini et al. 2004). ZAR1transcripts have been found in immature oocytes and in early embryos until major activation of the embryonic genome (Brevini et al. 2004, Nowak-Imialek et al. 2008).

An important nutrient for oocytes is glucose and its derivatives. Among others, it is transported into the cells by the glucose transporter 1 (SLC2A1; Morita et al. 1992). Although glucose cannot be utilized by the oocyte itself, the embryo until the two to four cell stage due to low hexokinase activity (Brinster 1965), SLC2A1 mRNA transcripts are present in immature and matured oocytes (Lequarre et al. 1997, Rajhans et al. 2010).
In vitro culture systems expose oocytes to a variety of environmental influences. The difference in mRNA levels for $S L C 2 A 1$ in our previous study (Oropeza et al. 2004) in two to four cell embryos from untreated and IGF1-treated calves was not reflected in the retrieved oocytes in this study. Different antioxidant systems are active to protect oocytes from reactive oxygen species (Guérin et al. 2001). PRDX1 expression was detected in immature and matured bovine oocytes and zygotes. It was significantly higher in matured adult oocytes compared with oocytes from prepubertal oocytes (Romar et al. 2011). In this study no significant influence of age and/or treatment was found regarding PRDX1 expression.

These data demonstrate that neither gene-specific expression nor methylation levels were different in the various treatment or age groups. Only IVM reduced abundance of the analyzed transcripts. In contrast to individual promoters, the methylation levels of the investigated satellite sequences were high $(>50 \%)$ in all groups and showed significant variation depending on the age, treatment, or IVM. Although we did not detect methylation changes in the three studied genes, the observed changes in satellite DNA methylation suggest a role of DNA methylation in the acquisition of developmental capacity of bovine oocytes, which needs to be explored in future studies. The in-depth understanding of DNA methylation and gene expression dynamics in oocytes is critical for developing improved IVP protocols for oocytes from prepubertal and adult donors.

\section{Materials and Methods}

\section{Animals and treatments}

All animal experiments were conducted in compliance with German Animal welfare regulations. A total of 105 prepubertal calves (6-9 months of age) and 43 cows ( $\geq 2$ nd lactation) from the experimental herd of the Institute in Mariensee were used for these experiments. Only healthy animals with adequate development of the reproductive tract were included in the experiments. Oocytes were collected over 3-week periods at intervals of 3-4 days by ultrasound-guided OPU after the initial removal of the dominant follicle 4 days prior to the first OPU session (Zaraza et al. 2010).

Calves were randomly assigned to four groups, i.e. calf, without treatment; calf $\mathrm{FSH}$, i.m. FSH treatment; calf FSH+ IGF1, i.m. FSH treatment + i.o. IGF1 injection; and calf FSH+ IGF C, FSH + i.o. $0.01 \mathrm{M}$ acetic acid injection (Table 5). Calves in groups 2, 3, and 4 all received one i.m. injection of $65 \mu \mathrm{g} \mathrm{FSH}$ (Stimufol; kindly provided by J F Beckers, University of Liege, Belgium) in order to promote the follicular growth $48 \mathrm{~h}$ prior to each OPU session. At the same time, groups 3 and 4 additionally received i.o. injections of $6 \mu \mathrm{g}$ rhIGF1 (R\&D Systems, Wiesbaden, Germany) or $0.01 \mathrm{M}$ acetic acid as vehicle control respectively at two distinct localizations of each ovary (Table 5).

Cows were randomly assigned to two treatment groups. Cows in the first group remained untreated (cow); cows in the 
Table 5 Overview of experimental design and treatment groups.

\begin{tabular}{lcccc}
\hline Group & $\begin{array}{c}\text { No treatment } \\
\text { (control) }\end{array}$ & FSH & FSH+ IGF1 & FSH + IGF C \\
\hline $\begin{array}{c}\text { Cow }(\geq 2 \text { nd } \\
\text { lactation) }\end{array}$ & + & + & - & - \\
$\begin{array}{c}\text { Calf }(6-9 \\
\text { months) }\end{array}$ & + & + & + & + \\
\hline
\end{tabular}

second group were injected i.m. with $100 \mu \mathrm{g}$ FSH (Stimufol) $48 \mathrm{~h}$ prior to each session (cow FSH). This is the standard dose of FSH for healthy adult female cows subject to superovulatory treatment.

\section{Ultrasound equipment and oocyte retrieval}

Ultrasound-guided OPU was performed as previously described (Oropeza et al. 2004, Zaraza et al. 2010). Briefly, ovaries were visualized using a CS9000 ultrasound system (Picker, München, Germany) and a $6.5 \mathrm{MHz}$ ultrasound transducer (Picker model, EUP-F-331). The ultrasound transducer was protected by a sanitary cover (Servoprax, Wesel, Germany) and was coated with lubricant (Bovivet gel; Kruuse, Langeskov, Denmark) before insertion into the vagina. Follicles 3-17 mm in diameter were aspirated using disposable 20G $23 / 4$ needles (Terumo, Eschborn, Germany) and a flexible tube system $(2 \mathrm{~mm} \times 1 \mathrm{~m})$ attached to a vacuum pump (IVF Ultra quiet; Cook Veterinary Products, Moenchengladbach, Germany) set to $8.3-8.4 \mathrm{hPa}$. The collected oocytes were flushed from the system after aspiration of four to five follicles, with Dulbecco's PBS medium (AppliChem, Darmstadt, Germany) containing 1\% heat-inactivated New Born Calf Serum (NBCS; PAA Laboratories, Coelbe, Germany), $36 \mu \mathrm{g} / \mathrm{ml}$ Na pyruvate (AppliChem), $1 \mathrm{mg} / \mathrm{ml}$ glucose (Roth, Karlsruhe, Germany), $133 \mu \mathrm{g} / \mathrm{ml}$ calcium chloride dehydrate (Fluka, Munich, Germany), $50 \mu \mathrm{g} / \mathrm{ml}$ streptomycin (AppliChem), $6 \mu \mathrm{g} / \mathrm{ml}$ penicillin G (AppliChem), and $2.2 \mathrm{IU} / \mathrm{ml} \mathrm{Na}$ heparin (Applichem). The fluid from each animal was kept in separate $50 \mathrm{ml}$ tubes, passed through a $50 \mu \mathrm{m}$ filter (Jürgens, Hannover, Germany), and washed with fresh PBS medium. Cumulusoocyte-complexes (COCs) were flushed from the filter with PBS and retrieved under a stereomicroscope at $\times 50$ magnification. COCs were collected in individual $50 \mu \mathrm{l} \mathrm{TCM}$-air drops, at pH 7.2 (TCM199; Sigma-Aldrich), containing $50 \mu \mathrm{g} / \mathrm{ml}$ gentamicin sulfate (Sigma-Aldrich), $0.2 \mathrm{mM} \mathrm{Na}$ pyruvate (Sigma-Aldrich), $4.2 \mathrm{mM} \mathrm{NaHCO} 3$ (Roth), and $1 \mathrm{mg} / \mathrm{ml} \mathrm{BSA}$ (FAF; Sigma-Aldrich) for each animal. Subsequently, the quality of the COCs was evaluated based on the homogeneity of the cytoplasm and the surrounding cumulus cells and only COCs morphologically classified into classes I and II (Looney et al. 1994, Goodhand et al. 1999) were used in this study.

\section{Treatment of COCs}

One group of COCs was immediately treated with PBS

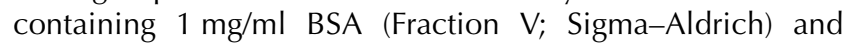
$0.1 \%$ hyaluronidase (Sigma-Aldrich) for $5 \mathrm{~min}$ at $39{ }^{\circ} \mathrm{C}$ followed by vortexing at 1400 r.p.m. for $5 \mathrm{~min}$ to remove adhering cumulus cells; any remaining cumulus cells were removed by careful pipeting of the oocytes. Denuded oocytes were washed three times in TCM-air and three times in PBS containing $0.1 \%$ polyvinyl alcohol and then frozen at $-80{ }^{\circ} \mathrm{C}$ in pools of ten for gene-specific methylation analysis, in pools of five for DNA repeat analysis or singly for quantitative realtime PCR (qPCR).

A second group of randomly selected oocytes were subjected to IVM as described recently (Heinzmann et al. 2011). Briefly, COCs were washed three times in TCM199 at $\mathrm{pH} 7.4$ supplemented with $0.2 \mathrm{mM} \mathrm{Na}$ pyruvate (SigmaAldrich), $25 \mathrm{mM} \mathrm{NaHCO}$ (Roth), $1 \mathrm{mg} / \mathrm{ml}$ BSA (FAF; SigmaAldrich). Subsequently, groups of five to ten washed COCs were placed in $50 \mu \mathrm{l}$ drops of supplemented TCM199 containing $10 \mathrm{IU} / \mathrm{ml}$ of equine chorionic gonadotropin and $5 \mathrm{IU} / \mathrm{ml}$ of human chorionic gonadotropin (Suigonan; Intervet, Unterschleissheim, Germany) under silicone oil (Serva, Heidelberg, Germany) and incubated at $39{ }^{\circ} \mathrm{C}$ in a humidified atmosphere of $5 \% \mathrm{CO}_{2}$ in air for $24 \mathrm{~h}$. Successful maturation was confirmed after the removal of cumulus cells under the stereomicroscope by visualization of the first polar body. COCs were treated according to the protocol for immature oocytes above and frozen at $-80{ }^{\circ} \mathrm{C}$ until further use.

\section{mRNA isolation and RT}

The relative transcript levels of four developmentally important genes were investigated on single cell basis. Poly $(\mathrm{A})^{+}$RNA was recovered from single oocytes using Dynabeads mRNA DIRECT Kit (Invitrogen; Heinzmann et al. 2011). Briefly, $40 \mu \mathrm{l}$ lysis/binding buffer (100 mM Tris- $\mathrm{HCl}(\mathrm{pH} 8.0)$, $500 \mathrm{mM} \mathrm{LiCl}, 10 \mathrm{mM}$ EDTA, 1\% lithium dodecyl sulfate, and $5 \mathrm{mM}$ dithiothreitol) were added to the frozen single oocytes ( $n=15$ per group) and incubated at room temperature for $10 \mathrm{~min}$. For normalization purposes $1 \mathrm{pg}$ rabbit globin mRNA (BRL, Gaithersburg, MD, USA) was added as an exogenous standard. This is necessary as degradation and deadenylation of transcripts in the growing and maturing oocyte inhibit the use of endogenous housekeeping genes for normalization and normalization to an exogenous standard has been successfully used in previous studies from our laboratory and others (Wrenzycki et al. 2001, Thélie et al. 2007, Niemann et al. 2010). A total of $5 \mu$ pre-equilibrated Dynabeads Oligo $\mathrm{d}(\mathrm{T})_{25}$ were added to the lysate and binding of mRNA to the magnetic beads was facilitated by incubation at $25^{\circ} \mathrm{C}$ on a shaker for $15 \mathrm{~min}$. Subsequently, a Dynal MPC-E-1 magnetic separator was used to separate the poly $(\mathrm{A})^{+} \mathrm{RNA}$ bound to the beads. The beads and mRNA were washed twice as described (Wrenzycki et al. 2001) and finally mRNA was eluted by incubation in $11 \mu \mathrm{l}$ sterile water for $2.5 \mathrm{~min}$ at $68^{\circ} \mathrm{C}$. The recovered $m R N A$ was immediately transcribed into cDNA (RT).

RT was performed in a volume of $20 \mu \mathrm{l}$ with $10 \times \mathrm{RT}$ reaction buffer (Invitrogen), supplemented with $5 \mathrm{mM} \mathrm{MgCl}_{2}$ (Invitrogen), $1 \mathrm{mM}$ dNTP solution (Amersham Biosciences), $2.5 \mu \mathrm{M}$ random hexamer primers (Applied Biosystems, Darmstadt, Germany), $20 \cup$ RNAsin (Applied Biosystems), and $50 \mathrm{U}$ murine leukemia virus reverse transcriptase (Applied Biosystems) in a total of $11 \mu \mathrm{lmRNA}$ sample. RT was performed in a thermal cycler with a program of $25^{\circ} \mathrm{C}$ for $10 \mathrm{~min}$ for primer annealing and then $1 \mathrm{~h}$ at $42{ }^{\circ} \mathrm{C}$ for elongation and finally 5 min at $99^{\circ} \mathrm{C}$. The eluted cDNA was directly used for qPCR. 
Table 6 Primers used for quantitative real-time PCR.

\begin{tabular}{|c|c|c|c|c|}
\hline Gene & Primer sequences $\left(5^{\prime}-3^{\prime}\right)$ & Annealing temp./no. of cycles $\left({ }^{\circ} \mathrm{C}\right)$ & Amplicon length (bp) & Accession no. \\
\hline \multirow[t]{2}{*}{ GDF9 } & F: CGGTATGGCTCTCCAGTTCAC & 60 & 69 & NM_174681.2 \\
\hline & R: TGGCACTGAGGAGTCAAGTTTC & 40 & & \\
\hline \multirow[t]{2}{*}{$S L C 2 A 1$} & F: CAGGAGATGAAGGAGGAGC & 60 & 258 & NM_174602.2 \\
\hline & R: CACAAATAGCGACACGACAG & 40 & & \\
\hline \multirow{2}{*}{$P R D X 1$} & F: TCAAGCCTGATGTCCAGAAGAGC & 60 & 173 & NM_174431.1 \\
\hline & R: CCGTCCTGTCCСТАСАCСAC & 40 & & \\
\hline \multirow[t]{2}{*}{ ZAR1 } & F: AGACTAGATGCTCСТGСССАGT & 60 & 82 & NM_001076203.1 \\
\hline & R: TCTTGACGGTGGGGCCGTTTAG & 40 & & \\
\hline \multirow{2}{*}{ Globin } & F: GCAGCCACGGTGGCGAGTAT & 60 & 257 & X04751 \\
\hline & R: GTGGGACAGGAGCTTGAAAT & 40 & & \\
\hline
\end{tabular}

\section{Quantitative real-time PCR}

qPCR was performed as described recently by our laboratory (Niemann et al. 2010, Heinzmann et al. 2011). Twenty microliter reactions were set up in 96 well optical plates (Applied Biosystems). Each well contained $10 \mu \mathrm{l} 2 \times$ Power SYBR_Green PCR Master Mix (Applied Biosystems), $0.2 \mu \mathrm{M}$ each of the forward and reverse primers, $2 \mu \mathrm{l}$ cDNA (equivalent of 0.1 oocyte), and $6.4 \mu \mathrm{H}_{2} \mathrm{O}$. The primer sequences and fragment sizes used for mRNA transcript analyses are summarized in Table 6.

An ABI 7500 Fast Real-Time System (Applied Biosystems) was used on a program consisting of $10 \mathrm{~min}$ at $95{ }^{\circ} \mathrm{C}(\mathrm{CDNA}$ denaturation and Taq polymerase activation), and 40 cycles at $95{ }^{\circ} \mathrm{C}$ for $15 \mathrm{~s}, 60{ }^{\circ} \mathrm{C}$ for $1 \mathrm{~min}$, and a final slow heating cycle to obtain the dissociation curves.

The cDNA dilution standards of pooled oocyte mRNA from adult cows and rabbit globin CDNA were included on every plate to provide standard curves for each gene. Standard curves were used to calculate the relative amount of each target gene to be normalized to the signal of the added globin mRNA. Sequence Detection Software 1.3.1 (Applied Biosciences) was used for quantification.

\section{Methylation analyses}

\section{Repeat analyses}

The developmental stage-specific methylation profiles of the bovine repeat sequences, BTS DNA, segment 2 (GenBank: J00032.1), and BT $\alpha$ S DNA (GenBank: AJ293510.1) were analyzed in pools from all experimental groups using pools of five immature or five in vitro matured oocytes (Kang et al. 2005). DNA extraction and bisulfite conversion were performed simultaneously using the EZ DNA Methylation-Direct
Kit (Zymo Research, Irvine, CA, USA). Briefly, oocytes were treated with $13 \mu \mathrm{l}$ M Digestion Buffer, $1 \mu \mathrm{l}$ Proteinase $\mathrm{K}$, and $12 \mu \mathrm{l} \mathrm{H}_{2} \mathrm{O}$ at $50{ }^{\circ} \mathrm{C}$ for $20 \mathrm{~min}$ and subsequently centrifuged for 5 min at 10000 r.p.m. in a bench top centrifuge. Bisulfite conversion was performed in a thermal cycler with a program of $8 \mathrm{~min}$ at $98{ }^{\circ} \mathrm{C}, 3.5 \mathrm{~h}$ at $64{ }^{\circ} \mathrm{C}$ and $4{ }^{\circ} \mathrm{C}$ for storage after addition of $130 \mu \mathrm{l} \mathrm{CT}$ Conversion Reagent to $20 \mu \mathrm{l}$ of the supernatant. Cleanup of the converted DNA was performed using the ZYMO-Spin IC column and buffers provided in the kit according to the manufacturer's instructions. After final elution, the DNA was stored at $-20^{\circ} \mathrm{C}$ until further use. Analysis of the bisulfite-treated oocyte DNA was performed according to Kang et al. (2005) with slight modifications. Briefly, satellite sequence-specific PCR fragments were amplified using the primers and PCR conditions summarized in Table 7.

Successful amplification was confirmed by agarose gel electrophoresis and PCR products were cleaned up using the Wizard SV Gel and PCR Clean-Up System Kit (Promega) according to the manufacturer's instructions. PCR products were ligated into the pGEM-T easy vector using the pGEM-T easy vector system (Promega) according to the manual and transformed into Escherichia coli XL10-Gold cells (Stratagene, Santa Clara, CA, USA).

Individual clones were picked and directly used for amplification of the insert using the universal T7 and SP6 primers (Table 7). These primers were also used for subsequent sequencing. Twenty-four bacterial clones per analyzed pool were sequenced and the BiQ Analyzer (MPI for Informatics, Saarland, Germany) was used for data analysis.

Table 7 Primers for analysis of repeat sequences.

\begin{tabular}{|c|c|c|c|c|}
\hline Repeat/binding site & Primer sequences $\left(5^{\prime}-3^{\prime}\right)$ & $\begin{array}{c}\text { Annealing } \\
\text { temp./no. of cycles }\left({ }^{\circ} \mathrm{C}\right)\end{array}$ & Amplicon length (bp) & GenBank \\
\hline \multirow{2}{*}{ BTS sequence } & F: ААТАССТСТААТTТСАААСТ & 49 & 221 & AH001157.1 \\
\hline & R: TTTGTGAATGTAGTTAATA & 35 & & \\
\hline \multirow[t]{2}{*}{$\mathrm{BT} \alpha \mathrm{S}$ sequence } & F: GATGTTTTYGGGGAGAGAGG & 61 & 154 & AJ293510.1 \\
\hline & R: CCRATCCCCTCTTAATAAAAACC & 35 & & \\
\hline T7 & ACT CAC TAT AGG GCG AAT TG & 55 & & \\
\hline SP6 & ATT TAG GTG ACA CTA TAG AAT ACT C & 35 & & \\
\hline
\end{tabular}




\section{Gene-specific methylation}

Methylation patterns of the promoter regions of the developmentally important genes $S L C 2 A 1, P R D X 1$, and $Z A R 1$ were analyzed in immature oocytes and in in vitro matured oocytes retrieved from follicles $>3 \mathrm{~mm}$ by OPU. For $S L C 2 A 1$, the analyzed CpG sites lie between -225 and -384 bp relative to the transcription start site (TSS) of the mRNA, while the CpG sites of PRDX1 and ZAR1 are located between -160 and $+11 \mathrm{bp}$ and -192 and -15 bp respectively relative to the mRNATSS. In total, nine pools of oocytes in the group ' $\mathrm{Cow}^{\prime}$ (four immature/five IVM), five pools in the groups 'calf' (1/4), nine in 'calf FSH' (5/4) and eight in 'Cow FSH' (4/4), seven pools in the group 'calf FSH+IGF1' (3/4), and six pools in the group 'calf FSH+IGF C' (3/3) were analyzed. Bisulfite sequencing after limiting dilution is compatible with the analysis of minimum amounts of DNA from pools of only a few cells (El Hajj et al. 2011, Heinzmann et al. 2011). In the present study, the bisulfite conversion rate was $95-100 \%$. Ten microliters of bisulfite-treated DNA (EZ DNA Methylation-Direct Kit; Zymo Research) were diluted to a final volume of $520 \mu \mathrm{l}$ with PCR master mix (see below) and subsequently distributed into 20 PCR tubes $(26 \mu \mathrm{l}$ each). In a first amplification step, multiplex PCR containing the outer primers for the three genes was performed. Subsequently, gene-specific single PCRs with nested primers were used to amplify single DNA molecules. The sequencing performance of the CG-poor DNA was enhanced by tagging the inner primers with a stuffer sequence (Han et al. 2006) and further improved by additionally tagging the stuffer with an M13-tag. All primers used in multiplex and gene-specific PCR are summarized in Table 8 . Briefly, the multiplex PCR mastermix contained $12 \% 10 \times$ ammonium buffer (200 mM ammonium sulfate, $750 \mathrm{mM}$ Tris- $\mathrm{HCl}$, and $0.1 \%$ Tween 20), $240 \mu \mathrm{M}$ dNTPs (100 mM dNTP Set; Invitrogen), $2.4 \mathrm{mM}$ magnesium sulfate, $2.4 \times$ Enhancer $\left(10 \times \mathrm{PCR}_{X}\right.$ Enhancer Solution; Invitrogen), $0.4 \mu \mathrm{M}$ of each outer primer, and $1 \cup$ Platinum Taq (Invitrogen) per each $25 \mu \mathrm{l}$ of mastermix. Six negative controls were run $(6 \times 26 \mu \mathrm{l}$ mastermix $)$ to detect possible contamination during pipeting. For the second round of PCR, FastStart Taq Polymerase (Roche Diagnostics) was used according to the amplification protocol (Heinzmann et al. 2011).

Table 8 Primer sequences for direct bisulfite sequencing.

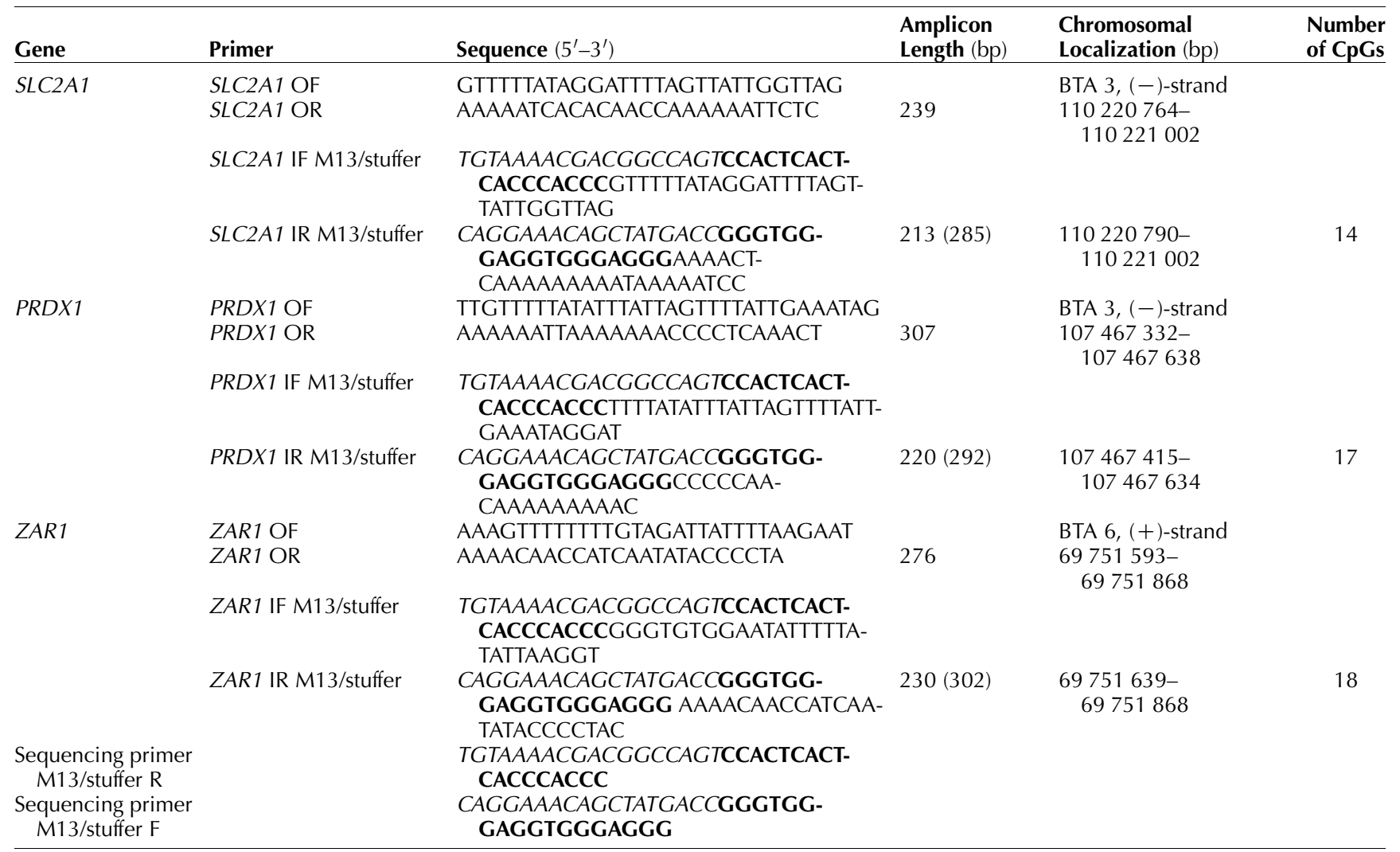

This table provides the primer sequences used for direct bisulfite sequencing of the studied genes, the length and chromosomal localization of the amplified segments (according to NCBI release of Btau_4.0, August 2010), and the number of CpG sites in the amplicons. O, outer primer; I, inner primer; F, forward primer; and R, reverse primer. Inner primers are tagged with an M13 (italic) and stuffer (bold) sequence. Amplicon length without brackets: original bovine bisulfite specific primed amplicon length; amplicon length in brackets: actual full amplicon length including M13/stuffer tag. 
The general PCR conditions were as follows: an initial denaturation step at $95{ }^{\circ} \mathrm{C}$ for 4 min was followed by $31-35$ cycles of $95^{\circ} \mathrm{C}$ for $30 \mathrm{~s}$, primer-specific annealing temperature for $30 \mathrm{~s}$ and $72{ }^{\circ} \mathrm{C}$ for $45 \mathrm{~s}$, and a final extension step at $72{ }^{\circ} \mathrm{C}$ for $5 \mathrm{~min}$. Multiplex PCR was performed with an annealing temperature of $54{ }^{\circ} \mathrm{C}$ for 35 cycles. In the gene-specific second round of PCR, SLC2A1 and ZAR1 products were amplified at an annealing temperature of $58{ }^{\circ} \mathrm{C}$ for 31 cycles and PRDX1 at $54{ }^{\circ} \mathrm{C}$ for 32 cycles. Sequencing of the resulting PCR products was done on an $\mathrm{ABI} 3130 \mathrm{xI}$ automated sequencer.

\section{Statistical analysis}

Kruskal-Wallis one-way ANOVA was used to analyze gene expression data (Siegel et al. 1988). Group comparison for the methylation analysis was performed using $\chi^{2}$-test or Fisher's test. In order to facilitate comparison between groups the 'pairwise.prop.test' (www.r-project.org) was used. For all tests, $P \leq 0.05$ was considered as being statistically significant.

\section{Supplementary data}

This is linked to the online version of the paper at http://dx.doi. org/10.1530/REP-12-0134.

\section{Declaration of interest}

The authors declare that there is no conflict of interest that could be perceived as prejudicing the impartiality of the research reported.

\section{Funding}

The authors are grateful to the $\mathrm{H}$. Wilhelm Schaumann Foundation, Hamburg for the fellowship to M Diederich, and the DFG research group Germ cell potential (Ni 256/30-1 and HA 1374/10-2) for the financial support of this study.

\section{Acknowledgement}

The authors are grateful to H-G Sander, R Poppenga, G Möller, G Scharnhorst, K Korsawe, and M Streeck for their expert technical assistance throughout this study.

\section{References}

Anckaert E, Romero S, Adriaenssens T \& Smitz J 2010 Effects of low methyl donor levels in culture medium during mouse follicle culture on oocyte imprinting establishment. Biology of Reproduction 83 377-386. (doi:10.1095/biolreprod.109.082164)

Antequera F \& Bird A 1993 Number of CpG islands and genes in human and mouse. PNAS 90 11995-11999. (doi:10.1073/pnas.90.24. 11995)
Brevini TA, Cillo F, Colleoni S, Lazzari G, Galli C \& Gandolfi F 2004 Expression pattern of the maternal factor zygote arrest 1 (Zar1) in bovine tissues, oocytes, and embryos. Molecular Reproduction and Development 69 375-380. (doi:10.1002/mrd.20140)

Brinster RL 1965 Studies on the development of mouse embryos in vitro. II. The effect of energy source. Journal of Experimental Zoology 158 59-68. (doi:10.1002/jez.1401580106)

Cheung HH, Lee TL, Rennert OM \& Chan WY 2009 DNA methylation of cancer genome. Birth Defects Research. Part C, Embryo Today: Reviews 87 335-350. (doi:10.1002/bdrc.20163)

De Paz P, Sánchez AJ, De la Fuente J, Chamorro CA, Alvarez M, Anel E \& Anel L 2001 Ultrastructural and cytochemical comparison between calf and cow oocyte. Theriogenology 55 1107-1116. (doi:10.1016/S0093691X(01)00470-8)

Duranthon V \& Renard JP 2001 The developmental competence of mammalian oocytes: a convenient but biologically fuzzy concept. Theriogenology 55 1277-12789. (doi:10.1016/S0093-691X(01) 00482-4)

El Hajj N, Trapphoff T, Linke M, May A, Hansmann T, Kuhtz J, Reifenberg K, Heinzmann J, Niemann H, Daser A et al. 2011 Limiting dilution bisulfite (pyro)sequencing reveals parent-specific methylation patterns in single early mouse embryos and bovine oocytes. Epigenetics 6 1176-1188. (doi:10.4161/epi.6.10.17202)

Fagundes NS, Michalczechen-Lacerda VA, Caixeta ES, Machado GM, Rodrigues FC, Melo EO, Dode MA \& Franco MM 2011 Methylation status in the intragenic differentially methylated region of the IGF2 locus in Bos taurus indicus oocytes with different developmental competencies. Molecular Human Reproduction 17 85-91. (doi:10.1093/ molehr/gaq075)

Fair T, Hyttel P \& Greve T 1995 Bovine oocyte diameter in relation to maturational competence and transcriptional activity. Molecular Reproduction and Development 424 437-442. (doi:10.1002/mrd. 1080420410)

Goodhand KL, Watt G, Staines ME, Hutchinson JS \& Broadent PJ 1999 In vivo oocyte recovery and in vitro embryo production from bovine aspirated at different frequencies or following FSH treatment. Theriogenology 51 951-961. (doi:10.1016/S0093-691X(99)00041-2)

Griswold MD \& Kim JS 2001 Site-specific methylation of the promoter alters deoxyribonucleic acid-protein interactions and prevents follicle-stimulating hormone receptor gene transcription. Biology of Reproduction 64 602-610. (doi:10.1095/biolreprod64.2.602)

Guérin P, El Mouatassim S \& Ménézo Y 2001 Oxidative stress and protection against reactive oxygen species in the pre-implantation embryo and its surroundings. Human Reproduction Update 7 175-189. (doi:10.1093/humupd/7.2.175)

Haaf T 1995 The effects of 5-azacytidine and 5-azadeoxycytidine on chromosome structure and function: implications for methylationassociated cellular processes. Pharmacology \& Therapeutics 65 19-46. (doi:10.1016/0163-7258(94)00053-6)

Han W, Cauchi S, Herman JG \& Spivack SD 2006 DNA methylation mapping by tag-modified bisulfite genomic sequencing. Analytical Biochemistry 355 50-61. (doi:10.1016/j.ab.2006.05.010)

Heinzmann J, Hansmann T, Herrmann D, Wrenzycki C, Zechner U, Haaf T \& Niemann H 2011 Epigenetic profile of developmentally important genes in bovine oocytes. Molecular Reproduction and Development $\mathbf{7 8}$ 188-201. (doi:10.1002/mrd.21281)

Hyttel P, Fair T, Callesen H \& Greve T 1997 Oocyte growth, capacitation and final maturation in cattle. Theriogenology 47 23-32. (doi:10.1016/ S0093-691X(96)00336-6)

Jaenisch R 1997 DNA methylation and imprinting: why bother? Trends in Genetics 13 323-329. (doi:10.1016/S0168-9525(97)01180-3)

Jaenisch R \& Bird A 2003 Epigenetic regulation of gene expression: how the genome integrates intrinsic and environmental signals. Nature Genetics 33 (Suppl) 245-254. (doi:10.1038/ng1089)

Kageyama S, Liu H, Kaneko N, Ooga M, Nagata M \& Aoki F 2007 Alterations in epigenetic modifications during oocyte growth in mice. Reproduction 133 85-94. (doi:10.1530/REP-06-0025)

Kang YK, Koo DB, Park JS, Choi YH, Chung AS, Lee KK \& Han YM 2001 Aberrant methylation of donor genome in cloned bovine embryos. Nature Genetics 28 173-177. (doi:10.1038/88903)

Kang YK, Lee HJ, Shim JJ, Yeo S, Kim SH, Koo DB, Lee KK, Beyhan Z, First NL \& Han YM 2005 Varied patterns of DNA methylation change 
between different satellite regions in bovine preimplantation development. Molecular Reproduction and Development 71 29-35. (doi:10.1002/mrd.20249)

Katari S, Turan N, Bibikova M, Erinle O, Chalian R, Foster M, Gaughan JP, Coutifaris C \& Sapienza C 2009 DNA methylation and gene expression differences in children conceived in vitro or in vivo. Human Molecular Genetics 18 3769-3778. (doi:10.1093/hmg/ddp319)

Kauffold J, Amer HA, Bergfeld U, Weber W \& Sobiraj A 2005 The in vitro development competence of oocytes from juvenile calves is related to follicular diameter. Journal of Reproduction and Development $\mathbf{5 1}$ 325-332. (doi:10.1262/jrd.17002)

Laird PW 2005 Cancer epigenetics. Human Molecular Genetics 14 R65-R76. (doi:10.1093/hmg/ddi113)

Lees-Murdock DJ \& Walsh CP 2008 DNA methylation reprogramming in the germ line. Epigenetics 3 5-13. (doi:10.4161/epi.3.1.5553)

Lequarre AS, Grisart B, Moreau B, Schuurbiers N, Massip A \& Dessy F 1997 Glucose metabolism during bovine preimplantation development: analysis of gene expression in single oocytes and embryos. Molecular Reproduction and Development 48 216-226. (doi:10.1002/(SICI)1098-2795(199710)48:2<216::AID-MRD9>3.0. $\mathrm{CO} ; 2-\mathrm{V})$

Lohuis MM 1995 Potential benefits of bovine embryo manipulation technologies in genetic improvement programs. Theriogenology $\mathbf{4 3}$ 51-60. (doi:10.1016/0093-691X(94)00016-N)

Lonergan P, Monaghan P, Rizos D, Boland MP \& Gordon I 1994 Effect of follicle size on bovine oocyte quality and developmental competence following maturation, fertilization, and culture in vitro. Molecular Reproduction and Development 37 48-53. (doi:10.1002/ mrd.1080370107)

Lonergan P, Gutierrez-Adan A, Rizos D, Pintado B, de la Fuente J \& Boland MP 2003 Relative messenger RNA abundance in bovine oocytes collected in vitro or in vivo before and $20 \mathrm{~h}$ after the preovulatory luteinizing hormone surge. Molecular Reproduction and Development 66 297-305. (doi:10.1002/mrd.10357)

Looney CR, Lindsey BR, Gonseth CL \& Johnson DL 1994 Commercial aspects of oocyte retrieval and in vitro fertilization (IVF) for embryo production in problem cows. Theriogenology 41 67-72. (doi:10.1016/ S0093-691X(05)80050-0)

Lucifero D, Mertineit C, Clarke HJ, Bestor TH \& Trasler JM 2002 Methylation dynamics of imprinted genes in mouse germ cells. Genomics 79 530-538. (doi:10.1006/geno.2002.6732)

Maunakea AK, Nagarajan RP, Bilenky M, Ballinger TJ, D'Souza C, Fouse SD, Johnson BE, Hong C, Nielsen C, Zhao Y et al. 2010 Conserved role of intragenic DNA methylation in regulating alternative promoters. Nature 466 253-257. (doi:10.1038/nature09165)

Memili E \& First NL 2000 Zygotic and embryonic gene expression in cow: a review of timing and mechanisms of early gene expression as compared with other species. Zygote 8 87-96. (doi:10.1017/S096719 9400000861)

Miniou $P$, Jeanpierre $M$, Blanquet $V$, Sibella $V$, Bonneau D, Herbelin $C$, Fischer A, Niveleau A \& Viegas-Péquignot E 1994 Abnormal methylation pattern in constitutive and facultative ( $\mathrm{X}$ inactive chromosome) heterochromatin of ICF patients. Human Molecular Genetics 3 2093-2102. (doi:10.1093/hmg/3.12.2093)

Monk M, Boubelik M \& Lehnert S 1987 Temporal and regional changes in DNA methylation in the embryonic, extraembryonic and germ cell lineages during mouse embryo development. Development 99 371-382.

Morita Y, Tsutsumi O, Hosoya I, Taketani Y, Oka Y \& Kato T 1992 Expression and possible function of glucose transporter protein GLUT1 during preimplantation mouse development from oocytes to blastocysts. Biochemical and Biophysical Research Communications 188 8-15. (doi:10.1016/0006-291X(92)92342-U)

Neumann B \& Barlow DP 1996 Multiple roles for DNA methylation in gametic imprinting. Current Opinion in Genetics \& Development 6 159-163. (doi:10.1016/S0959-437X(96)80045-1)

Niemann H \& Wrenzycki C 2000 Alterations of expression of developmentally important genes in preimplantation bovine embryos by in vitro culture conditions: implications for subsequent development. Theriogenology 53 21-34. (doi:10.1016/S0093-691X(99)00237-X)
Niemann H, Carnwath JW, Herrmann D, Wieczorek G, Lemme E, Lucas-Hahn A \& Olek S 2010 DNA methylation patterns reflect epigenetic reprogramming in bovine embryos. Cellular Reprogramming 12 33-42. (doi:10.1089/cell.2009.0063)

Nowak-Imialek M, Wrenzycki C, Herrmann D, Lucas-Hahn A, Lagutina I, Lemme E, Lazzari G, Galli C \& Niemann H 2008 Messenger RNA expression patterns of histone associated genes in bovine preimplantation embryos derived from different origins. Molecular Reproduction and Development 75 731-743. (doi:10.1002/mrd.20816)

O'Doherty AM, O'Shea LC \& Fair T 2012 Bovine DNA methylation imprints are established in an oocyte size-specific manner, which are coordinated with the expression of the DNMT3 family proteins. Biology of Reproduction $\mathbf{8 6} 1-10$

Oropeza A, Wrenzycki C, Herrmann D, Hadeler KG \& Niemann H 2004 Improvement of the development capacity of oocytes from prepuberale cattle by intraovarian insulin-like growth factor-I application. Biology of Reproduction 70 1634-1643. (doi:10.1095/ biolreprod.103.025494)

Picton H, Briggs D \& Gosden R 1998 The molecular basis of oocyte growth and development. Molecular and Cellular Endocrinology 145 27-37. (doi:10.1016/S0303-7207(98)00166-X)

Ptak G, Matsukawa K, Palmieri C, Della Salda L, Scapolo PA \& Loi P 2006 Developmental and functional evidence of nuclear immaturity in prepubertal oocytes. Human Reproduction 21 2228-2237. (doi:10. 1093/humrep/del184)

Rajhans R, Kumar GS, Dubey PK \& Sharma GT 2010 Effect of timing of development on total cell number and expression profile of HSP-70.1 and GLUT-1 in buffalo (Bubalus bubalis) oocytes and preimplantation embryos produced in vitro. Cell Biology International 34 463-468. (doi:10.1042/CBI20090295)

Romar R, De Santis T, Papillier P, Perreau C, Thélie A, Dell'Aquila ME, Mermillod P \& Dalbiès-Tran R 2011 Expression of maternal transcripts during bovine oocyte in vitro maturation is affected by donor age. Reproduction in Domestic Animals 46 23-30. (doi:10.1111/j.14390531.2010.01617.x)

Sanford J, Forrester L, Chapman V, Chandley A \& Hastie N 1984 Methylation patterns of repetitive DNA sequences in germ cells of Mus musculus. Nucleic Acids Research 12 2823-2836. (doi:10.1093/nar/12. 6.2823)

Sato A, Otsu E, Negishi H, Utsunomiya T \& Arima T 2007 Aberrant DNA methylation of imprinted loci in superovulated oocytes. Human Reproduction 22 26-35. (doi:10.1093/humrep/del316)

Shi W \& Haaf T 2002 Aberrant methylation patterns at the two-cell stage as an indicator of early developmental failure. Molecular Reproduction and Development 63 329-334. (doi:10.1002/mrd.90016)

Siegel S, John N \& Castellan NJ 1988 Nonparametric Statistics for the Behavioral Sciences, pp 213-214, 2nd edn. New York, NY, USA: McGraw-Hill.

Siegfried Z \& Cedar H 1997 DNA methylation: a molecular lock. Current Biology 7 305-307. (doi:10.1016/S0960-9822(06)00144-8)

Sontag LB, Lorincz MC \& Georg Luebeck E 2006 Dynamics, stability and inheritance of somatic DNA methylation imprints. Journal of Theoretical Biology 242 890-899. (doi:10.1016/j.jtbi.2006.05.012)

Steeves TE, Gardner DK, Zuelke KA, Squires TS \& Fry RC 1999 In vitro development and nutrient uptake by embryos derived from oocytes of prepubertal and adult cows. Molecular Reproduction and Development 54 49-56. (doi:10.1002/(SICl)1098-2795(199909)54:1 <49::AIDMRD7 > 3.0.CO;2-2)

Suzuki MM \& Bird A 2008 DNA methylation landscapes: provocative insights from epigenomics. Nature Reviews. Genetics 9 465-476. (doi:10.1038/nrg2341)

Thélie A, Papillier P, Pennetier S, Perreau C, Traverso JM, Uzbekova $S$, Mermillod P, Joly C, Humblot P \& Dalbiès-Tran R 2007 Differential regulation of abundance and deadenylation of maternal transcripts during bovine oocyte maturation in vitro and in vivo. BMC Developmental Biology 7 125. (doi:10.1186/1471-213X-7-125)

Weber M, Hellmann I, Stadler MB, Ramos L, Pääbo S, Rebhan M \& Schübeler D 2007 Distribution, silencing potential and evolutionary impact of promoter DNA methylation in the human genome. Nature Genetics 39 457-466. (doi:10.1038/ng1990) 
Wilkins-Haug L 2009 Epigenetics and assisted reproduction. Current Opinion in Obstetrics \& Gynecology 21 201-206. (doi:10.1097/GCO. 0b013e32832d7b95)

Wrenzycki C, Herrmann D, Keskintepe L, Martins A Jr, Sirisathien S, Brackett B \& Niemann H 2001 Effects of culture system and protein supplementation on mRNA expression in pre-implantation bovine embryos. Human Reproduction 16 893-901. (doi:10.1093/humrep/16.5.893)

Yoder JA, Walsh CP \& Bestor TH 1997 Cytosine methylation and the ecology of intragenomic parasites. Trends in Genetics 13 335-340. (doi:10.1016/S0168-9525(97)01181-5)

Zaraza J, Oropeza A, Velazquez MA, Korsawe K, Herrmann D, Carnwath JW \& Niemann H 2010 Developmental competence and mRNA expression of preimplantation in vitro-produced embryos from prepubertal and postpubertal cattle and their relationship with apoptosis after intraovarian administration of IGF-1. Theriogenology 74 75-89. (doi:10.1016/j.theriogenology.2009.11.033)

Received 15 February 2012

First decision 12 March 2012

Revised manuscript received 5 June 2012

Accepted 25 June 2012 